\title{
First- and second-line therapy for advanced nonsmall cell lung cancer
}

\author{
J-P. Sculier* and D. Moro-Sibilot ${ }^{\#}$
}

ABSTRACT: The objectives for the treatment of advanced nonsmall cell lung cancer are palliative and include improvement of survival, symptom control, quality of life and cost. The level of evidence of these benefits is based on multiple randomised trials and meta-analyses. Cisplatinbased chemotherapy with one of the regimens shown to be effective should be preferred. Carboplatin may be substituted for cisplatin if medical contraindications exist. Nonplatinumbased regimens are indicated as first-line treatment for advanced nonsmall cell lung cancer in patients for whom platinum-based chemotherapy is contraindicated. Single drug chemotherapy may be considered in patients with poor performance status. The choice of the active drugs depends on the patient's medical condition. There is no conclusive evidence that high doses of cisplatin $\left(100-120 \mathrm{mg} \cdot \mathrm{m}^{-2}\right)$ provide better results than standard lower doses $\left(50-60 \mathrm{mg} \cdot \mathrm{m}^{-2}\right)$ in terms of survival. The optimal duration of chemotherapy is poorly documented in advanced nonsmall cell lung cancer. A minimum of four to six cycles is advised in responding patients. Second-line chemotherapy is now accepted as a standard and should be offered to patients with good performance status and failing platinum-based first-line chemotherapy. Evidence is in favour of docetaxel and in the case of adenocarcinoma and adequate renal function, pemetrexed is recommended.

KEYWORDS: Chemotherapy, nonsmall cell lung cancer, stage IIIB-IV

M edical treatment of advanced nonsmall cell lung cancer (NSCLC) has been improved over the last two decades, with the main increase in the number of active drugs, the development of effective regimens and the introduction of salvage therapy after failure of first-line treatment. The present review will focus on chemotherapy; targeted therapies will be covered in another article in the series.

\section{FIRST-LINE CHEMOTHERAPY}

The present section is based on the recently published guidelines of the European Lung Cancer Working Party (ELCWP) for advanced NSCLC [1, 2]. The current review will focus on several main questions concerning the first-line medical management of the disease.

\section{What benefits can patients expect from chemotherapy and what are the treatment objectives?}

Randomised trials have shown benefits in terms of palliation, improvement of survival, symptom control, quality of life and cost.

In total, 13 trials have assessed the effect of combination chemotherapy (cisplatin-based in all but one) versus supportive care alone [3-15]. One study included only patients with stage III NSCLC [10]. Two thirds of the trials showed statistically significant improvements in survival. In addition, four trials have compared single agent chemotherapy, using one of the newer drugs with best supportive care alone [16-19]. All but one [18] showed a significant survival improvement with chemotherapy.

Previous articles in this series: No. 1: De Wever W, Stroobants S, Coolen J, Verschakelen JA. Integrated PET/CT in the staging of nonsmall cell lung cancer: technical aspects and clinical integration. Eur Respir J 2009; 33: 201-212. No. 2: Rami-Porta R, Tsuboi M. Sublobar resection for lung cancer. Eur Respir J 2009; 33: 426-435. No. 3: McWilliams A, Lam B, Sutedja T. Early proximal lung cancer diagnosis and treatment. Eur Respir J 2009; 33: 656-665.

AFFILIATIONS

*Intensive Care and Thoracic Oncology, Institut Jules Bordet, Université Libre de Bruxelles (ULB), Brussels, Belgium, and

\#PMAC Thoracic Oncology Unit, Hôpital Albert Michalon, Grenoble, and Lung Cancer Research Group, Institut National de la Santé et de la Recherche Médicale, Institut A. Bonniot, Université Joseph Fourrier, La Tronche, France.

CORRESPONDENCE

J-P. Sculier

Dept of Critical Care and Thoracic Oncology, Institut Jules Bordet Université Libre Bruxelles (ULB)

1 rue Héger-Bordet

B - 1000 Brussels

Belgium

Fax: 3225343756

E-mail: sculier@bordet.be

Received:

August 262008

Accepted after revision:

September 112008

STATEMENT OF INTEREST

A statement of interest for D. Moro-

Sibilot can be found at

www.erj.ersjournals.com/misc/ statements.dtl
European Respiratory Journal Print ISSN 0903-1936 Online ISSN 1399-3003 


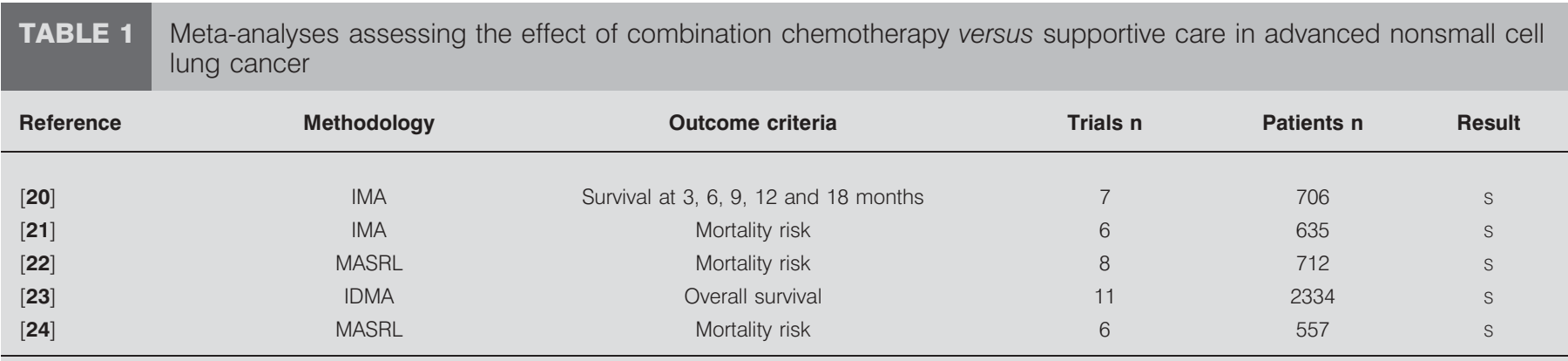

IMA: isolated meta-analysis of the literature; s: significant; MASRL: meta-analysis with systematic review of the literature; IDMA: meta-analysis based on individual patient data

Five meta-analyses [20-24], published in the 1990s and including one performed with individual patients data [23], have confirmed a modest but significant effect with chemotherapy in terms of survival (table 1). Symptom control has also been demonstrated as summarised in the American College of Chest Physicians (ACCP) guidelines [25], showing a high rate of improvement for cough, haemoptysis, pain, dyspnoea, weight loss, anorexia and malaise. Quality of life has been assessed in eight trials, with significant improvements in all but one (table 2). Finally, in terms of cost, RAPP et al. [4] have shown a reduced cost when chemotherapy is prescribed compared with supportive care alone [26].

\section{What are the active chemotherapeutic drugs for which efficacy has been shown?}

The drugs used in the published trials can be divided into three groups: inactive (also called first-generation); old (second-generation); and new (or modern or third-generation) drugs. The second-generation group of drugs has been the topic of a meta-analysis [27]. They include cisplatin, ifosfamide, mitomycin $C$, vindesine and vinblastine. Each of these drugs is able to significantly improve the response rate of the disease. The third-generation of active drugs has also been the subject of a systematic review [28]. They include gemcitabine, paclitaxel, docetaxel and vinorelbine, which are all available in Europe. In randomised trials, all of these drugs [16, 17, 19], except gemcitabine [18], have been shown to improve survival in comparison to supportive care alone.

\section{What are the recommended regimens for first-line chemotherapy?}

The recommendations of various scientific and academic associations are summarised in table 3. In their guidelines, the Ontario Program and the Fédération Nationale des Centres de Lutte Contre le Cancer (Paris, France) [29] recommend cisplatin-containing chemotherapy, without further precision of the drug(s) to be combined. For the ACCP, chemotherapy should be platinum-based with a new single agent $[25,30]$. According to the American Society of Clinical Oncology (ASCO), it should be a two-drug combination regimen [31]; nonplatinum containing chemotherapy may be used as an alternative to a platinum-based regimen. In patients with poor performance status, the ASCO recommends single-agent chemotherapy. For the ELCWP [2], cisplatin-based chemotherapy is proposed with one of the regimens shown to be effective. Single agent chemotherapy with a drug that is shown to be effective, may be considered in patients with poor performance status.

\section{TABLE 2}

Assessment of the effect of chemotherapy on quality care alone in advanced nonsmall cell lung cancer

\begin{tabular}{|c|c|c|c|}
\hline Reference & Chemotherapy regimen & Survival & Quality of life \\
\hline \multirow[t]{2}{*}{ [4] } & I. Cisplatin-adriamycine-cyclophosphamide & s & s \\
\hline & II. Cisplatin-vindesine & & \\
\hline [16] & Vinorelbine & s & s \\
\hline \multirow[t]{2}{*}{ [13] } & I. Cisplatin-epirubicine-ifosfamide & s & s \\
\hline & II. Cisplatin-mitomyocin-vinblastine & & \\
\hline [17] & Paclitaxel & s & s \\
\hline [18] & Gemcitabine & NS & s \\
\hline [19] & Docetaxel & $\mathrm{s}$ & $\mathrm{s}$ \\
\hline
\end{tabular}

S: significant; NS: nonsignificant. 
TABLE 3 Guidelines for the management of advanced nonsmall cell lung cancer

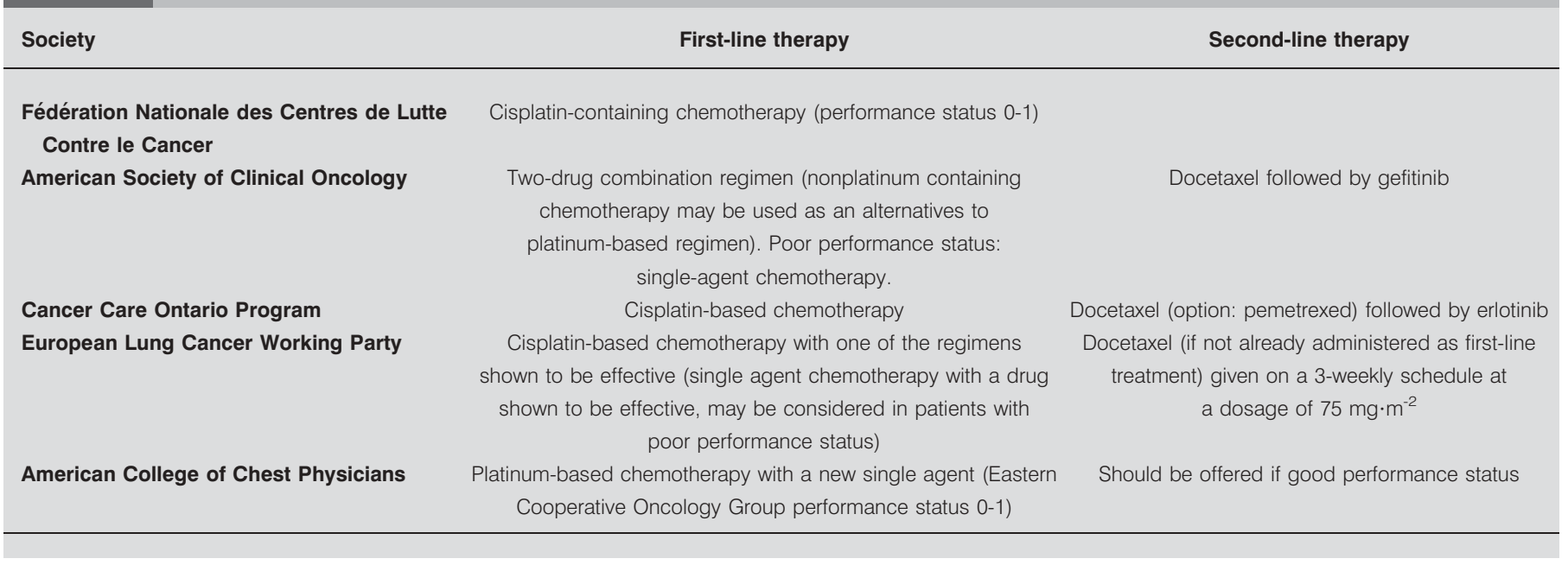

\section{What are the most effective platinum-based regimens for first-line chemotherapy?}

Many cisplatin-based regimens are commonly used, combining cisplatin with old drugs such as vindesine, mitomycin C and/or ifosfamide or new drugs such as gemcitabine, docetaxel, paclitaxel or vinorelbine.

Two types of meta-analyses are available to help choose the most effective regimen [32]. In the first type of meta-analyses (table 4), the trials are compared according to the number of drugs in the regimen. Polychemotherapy is associated with better results than single agent treatment $[33,34]$. Two-drug regimens are superior to one-drug regimen, both in terms of response and survival; three-drug combinations are better than two-drugs only in terms of response [35]. In the second type of meta-analyses (table 5), the role of specific drugs is analysed. Addition of a drug to a platinum derivative is beneficial in terms of survival [36] but not the addition of mitomycin-C to a basic chemotherapy regimen [37]. Gemcitabine appears to be associated with better outcomes in a meta-analysis of the literature but with much heterogeneity among the aggregated trials [38]. The combination of cisplatin with docetaxel does not appear to result in better survival in comparison to other cisplatin-based regimens [39] but seems superior to regimens based on platinum and vinca alkaloids [40]. In 2005, Canadian practice guidelines about the use of taxanes recommended paclitaxel or docetaxel plus cisplatin as one of a number of chemotherapy options in patients with good performance status [41]. Finally, a study group tried to compare regimens with second-generation or third-generation platinum-based regimens but decided to not perform survival aggregation because of too high a heterogeneity [42]. A recent systematic review of the literature on quality of life associated with standard chemotherapy in advanced NSCLC failed to show major differences between the various regimens [43].

In conclusion, chemotherapeutic regimens should include cisplatin with at least one other active drug. If the other drug is a new one, there is no evidence for the addition of a third agent outside the context of a clinical trial. There is also no evidence that combinations with new drugs are superior to those with old drugs in terms of survival. Cost of the treatment including supportive care and complications management should be taken into consideration in the choice of the regimen.

\section{What is the indicated dosage of cisplatin?}

There are five randomised trials that have investigated this question (table 6), all of which were performed with old drugs [44-48]. None of the studies were able to report a significant advantage in favour of high doses of cisplatin $\left(100-120 \mathrm{mg} \cdot \mathrm{m}^{-2}\right)$ in comparison to lower doses $\left(50-60 \mathrm{mg} \cdot \mathrm{m}^{-2}\right)$. In fact, the use of a high dose cisplatin is based on the observation of GRALLA et al. [44]

TABLE 4 Meta-analyses assessing the number of drugs needed in chemotherapy regimens

\begin{tabular}{|c|c|c|c|c|c|}
\hline & Methodology & Outcome criteria & Trials $\mathbf{n}$ & Patients n & Result \\
\hline \multicolumn{6}{|c|}{ Single agent versus polychemotherapy } \\
\hline MARINO [33] & MASRL & Mortality risk & 9 & 1493 & s \\
\hline LILENBAUM [34] & IMA & Survival at 6 and 12 months & 25 & 5156 & s \\
\hline \multicolumn{6}{|c|}{ One versus two drugs } \\
\hline DELBALDO [35] & IMA & Median survival & 30 & 6022 & s \\
\hline
\end{tabular}

MASRL: meta-analysis with systematic review of the literature; s: significant; IMA: isolated meta-analysis of the literature; NS: nonsignificant. 
TABLE 5 Meta-analyses assessing the role of particular chemotherapy drugs

\begin{tabular}{|c|c|c|c|c|c|}
\hline \multicolumn{6}{|c|}{ Addition of a drug to a platinum derivative } \\
\hline \multicolumn{6}{|c|}{ Addition of mitomycin to a basic chemotherapy regimen } \\
\hline SCULIER [37] & SRL with MA & Overall survival & 10 & 1769 & NS \\
\hline \multicolumn{6}{|c|}{$\begin{array}{l}\text { Role of chemotherapy with gemcitabine in comparison to } \\
\text { other chemotherapies }\end{array}$} \\
\hline \multicolumn{6}{|c|}{$\begin{array}{l}\text { Cisplatin and docetaxel versus other associations with } \\
\text { cisplatin }\end{array}$} \\
\hline SANCHEZ [39] & MA & Overall survival & 3 & 1980 & NS \\
\hline \multicolumn{6}{|c|}{ Docetaxel- versus vinca alkaloid-based chemotherapy } \\
\hline DOUILLARD [40] & MASRL & Survival & 7 & 2867 & s \\
\hline
\end{tabular}

MASRL: meta-analysis with systematic review of the literature; s: significant; SRL: standard review of the literature; MA: meta-analysis; NS: nonsignificant; NA: not analysed.

that responders to cisplatin plus vindesine survived longer when $120 \mathrm{mg} \cdot \mathrm{m}^{-2}$ of cisplatin was administered instead of $60 \mathrm{mg} \cdot \mathrm{m}^{-2}$. This difference was observed in a very small group of patients $(\mathrm{n}=35)$. The ELCWP was unable to replicate the results in a much higher number of patients [45]. High doses of cisplatin have the disadvantage of significantly higher renal, auditory and neurological toxicities [49].

Thus, there is no demonstration that high doses of cisplatin $\left(100-120 \mathrm{mg} \cdot \mathrm{m}^{-2}\right)$ provide better results in terms of survival than standard lower doses $\left(50-60 \mathrm{mg} \cdot \mathrm{m}^{-2}\right)$. Standard doses are associated with reduced toxicity and are thus recommended.

\section{Can carboplatin be substituted for cisplatin?}

The level of evidence is based on 10 published randomised trials [50-59] and three meta-analyses summarised in table 7 [60-62].
In randomised trials, the trend is in favour of cisplatin, both in terms of response and survival. The meta-analyses confirm this impression; the results are statistically significant in favour of cisplatin if the analysis is restricted to the regimens using new drugs combined with platinum derivatives.

Cisplatin should be preferred to carboplatin because of its better effect on survival. Carboplatin or a nonplatinum-based regimen may be prescribed if the patient is unable or unwilling to take cisplatin.

\section{What is the optimal number of cycles?}

The level of evidence is poor and based on a limited number of randomised trials, shown in table 8 . Two studies compared three cycles with six cycles $[63,64]$ or four cycles with six cycles [65] and another four cycles with treatment until disease

TABLE 6 Randomised trials assessing the role of the dose of cisplatin

\begin{tabular}{|c|c|c|c|c|c|c|}
\hline [44] & I. Cisplatin $\left(120 \mathrm{mg} \cdot \mathrm{m}^{-2}\right)+$ vindesine & 41 & 40 & NS & & NS \\
\hline \multirow[t]{3}{*}[45]{} & Cisplatin-VP16 & & & NS & & NS \\
\hline & I. $120 \mathrm{mg} \cdot \mathrm{m}^{-2}$ & $116(63)$ & 29 & & 28 weeks & \\
\hline & II. $60 \mathrm{mg} \cdot \mathrm{m}^{-2}$ & $125(76)$ & 25 & & 33 weeks & \\
\hline$[46]$ & II. Cisplatin $\left(80 \mathrm{mg} \cdot \mathrm{m}^{-2}\right)+$ vindesine & $21(16)$ & 33 & & 10.8 months & \\
\hline \multirow[t]{3}{*}[47]{} & Cisplatin & & & NS & & NS \\
\hline & 1. $2 \times 100 \mathrm{mg} \cdot \mathrm{m}^{-2}$ & $108(108)$ & 14 & & 5.3 months & \\
\hline & II. $2 \times 50 \mathrm{mg} \cdot \mathrm{m}^{-2}$ & 105 (105) & 12 & & 6.9 months & \\
\hline$[48]$ & Ifosfamide - mitomycin & & & NS & & NS \\
\hline
\end{tabular}


TABLE 7 Meta-analyses assessing platinum derivatives (cisplatin versus carboplatin)

\begin{tabular}{lccccc} 
Reference & Methodology & Outcome & Trials $\mathbf{n}$ & Patients $\mathbf{n}$ & Result \\
\hline$[60]$ & MASRL & Overall survival & 8 & 2903 & NS \\
{$[\mathbf{6 1}]$} & IDMA & Response and survival & 9 & 2968 & NS \\
{$[\mathbf{6 2}]$} & IMA & Response and survival & 18 & 6906 & NS \\
\hline
\end{tabular}

MASRL: meta-analysis with systematic review of the literature; NS: nonsignificant; IDMA: meta-analysis based on individual patient data; IMA: isolated meta-analysis of the literature.

progression [66]. The last trials compared maintenance treatment using paclitaxel [67], vinorelbine [68], gemcitabine [69, 70] versus observation after induction chemotherapy. In none of the studies was prolongation of chemotherapy demonstrated as an advantage.

Thus, it is reasonable to recommend a minimum of four to six cycles in responding patients. Prolongation with a single drug appears ineffective in terms of survival. The attitude to continue treatment until best response merits further assessment.

Can nonplatinum-based regimens be substituted for platinum-based chemotherapy as first-line treatment?

ASCO is the only scientific society recommending nonplatinum regimens as an alternative to platinum-based chemotherapy as first-line treatment of patients with advanced NSCLC [31]. All other societies recommend first-line platinum-based chemotherapy for advanced NSCLC patients. There are multiple randomised published trials on this topic [71-90]. In terms of survival, there is no statistically significant difference between the two types of treatment in all but one trial. In 2005, BARLESI and PUjoL [91] performed a systematic review of phase III trials available in the literature (table 9). They concluded that the approach is still debatable when doublet regimens with new drugs are considered and did not report a meta-analysis. D'ADDARIO et al. [92] have performed a meta-analysis of the published literature. When all trials were considered (irrespectively of using old or new drugs), there was a significant advantage both for response rate and 1-yr survival in favour of platinum-based treatment. The increase in 1-yr survival was $5 \%$.

TABLE 8 Randomised trials assessing the duration of chemotherapy

\begin{tabular}{|c|c|c|c|c|c|c|}
\hline Reference & Chemotherapy & Subjects $\mathrm{n}$ & OR \% & p-value & MST & p-value \\
\hline \multirow[t]{3}{*}{ [63] } & Cisplatin $\left(50 \mathrm{mg} \cdot \mathrm{m}^{-2}\right)+$ mitomycin + vinblastine & & & NS & & NS \\
\hline & I. Three cycles & 155 & 31 & & 6 months & \\
\hline & II. Six cycles & 153 & 32 & & 7 months & \\
\hline \multirow[t]{3}{*}{ [66] } & Carboplatin (AUC 6) + paclitaxel (200) & & & NS & & NS \\
\hline & I. Four cycles & 114 & 22 & & 6.6 months & \\
\hline & II. Until progression & 116 & 24 & & 8.5 months & \\
\hline \multirow[t]{3}{*}{ [67] } & Carboplatin + paclitaxel four cycles: CR-PR-NC & & & & & NS \\
\hline & I. Paclitaxel $70 \mathrm{mg} \cdot \mathrm{m}^{-2} \cdot$ week $^{-1} 3 / 4$ weeks & 66 & & & 75 weeks & \\
\hline & II. Observation & 65 & & & 60 weeks & \\
\hline \multirow[t]{3}{*}{ [68] } & Response to MIP & 573 & & & & NS \\
\hline & I. & 90 & & & 12.3 months & \\
\hline & II. Vinorelbine 6 months & 91 & & & 12.3 months & \\
\hline \multirow[t]{3}{*}{ [64] } & & & & & & NS \\
\hline & I. Carboplatin (AUC 4) + vinorelbine: three cycles & 150 & & & 28 weeks & \\
\hline & II. Carboplatin (AUC 4) + vinorelbine: six cycles & 147 & & & 32 weeks & \\
\hline \multirow[t]{3}{*}{ [69] } & Cisplatin $(80)+$ gemcitabine: four cycles: nonprogression & 354 & 21,6 & & & \\
\hline & I. Gemcitabine until progression & 138 & 50 & & 13 months & NS \\
\hline & II. Observation & 68 & 46 & & 11 months & \\
\hline \multirow[t]{3}{*}{ [70] } & Cisplatin $(75)+$ gemcitabine $\times 2$ & 340 & 29 & & $1 \mathrm{yr}$ & NS \\
\hline & I. Idem $\times 3$ & 125 & & & $52 \%$ & \\
\hline & II. Gemcitabine $\times 3$ & 125 & & & $32 \%$ & \\
\hline \multirow[t]{3}{*}{ [65] } & $\begin{array}{c}\text { Cisplatin }(70)+\text { taxane or gemcitabine: } 2 \times \text { and if } \\
\text { nonprogression }\end{array}$ & 452 & 29.5 & & & \\
\hline & I. Four cycles & 158 & 47.5 & NS & 14.9 months & NS \\
\hline & II. Two cycles & 156 & 41.6 & NS & 15.9 months & NS \\
\hline
\end{tabular}

OR: objective response; MST: median survival time; NS: nonsignificant; AUC: area under the curve; CR: complete response; PR: partial response; NC: no change; MIP: mitomycin + ifosfamide + cisplatin. 
TABLE 9 Meta-analyses assessing platinum-based regimens versus nonplatinum-based regimens

\begin{tabular}{lccccc} 
Reference & Methodology & Outcome & Trials $\mathbf{n}$ & Patients $\mathbf{~}$ & Result \\
\hline$[\mathbf{9 2}]$ & IMA & 1 yr survival & 30 & 6504 & Significant (in favour of platinum) \\
{$[\mathbf{9 3}]$} & MA & 1 yr risk of death & 11 & 4602 & Significant (in favour of platinum) \\
\hline
\end{tabular}

IMA: isolated meta-analysis of the literature; MA: meta-analysis. Regimens are for first-line treatment of nonsmall cell lung cancer

When the analysis was restricted to combination regimens with new drugs, there was no significant difference in survival but response rate was significantly improved with platinum-based treatment.

In conclusion, it is reasonable to recommend that nonplatinumbased regimens may be used as a first-line treatment for advanced NSCLC in cases where platinum-based chemotherapy is contraindicated. For all other patients, they should be used only in the context of clinical trials.

\section{Sequential chemotherapy}

Two phase II trials have been published on sequential chemotherapy (table 10) [94, 95]. The ELCWP completed a large phase III trial [95] where patients without disease progression after three courses of cisplatin-based chemotherapy were randomised between further platinum-based chemotherapy or paclitaxel with crossover at the time of progression. There was no difference in survival between the two approaches; however, there was a trend in favour of the nonsequential approach. There is thus no indication for sequential chemotherapy with taxanes (or other drugs) in the management of advanced NSCLC.

\section{Customised chemotherapy}

Customised or tailored chemotherapy results from a treatment decision based on an analysis of biomarkers of response and resistance to cytotoxic drugs. Evidence in favour of that approach comes from post hoc analysis of adjuvant chemotherapy trials in resected NSCLC [97-99] and from chemotherapy trials where the enzymes regulatory subunit of the ribonucleotide reductase and excision repair cross-complementation group (ERCC) 1 were assessed. If their increased expression is associated with a better prognosis after surgery [100], a lower expression in the tumour results in a better survival for platinum- and gemcitabine-based chemotherapy $[101,102]$. The first randomised trial performed on the topic showed an improved response rate when treatment was guided by the tumour ERCC1 expression [103].

\section{Targeted therapy}

Epidermal growth factor receptor (EGFR) tyrosine kinase inhibitors (TKIs), gefitinib and erlotinib, have been used as first-line therapy in combination with chemotherapy and results were disappointing. Three large randomised trials were conducted, two with gefitinib, by GIACCONE et al. [104] and HerbSt et al. [105], and one with erlotinib by HerbST et al. [106]. In a recent trial carried out in patients with poor performance status (performance status 2), erlotinib single-agent therapy was associated with significantly shorter survival in comparison with platinum-based chemotherapy [107].

Bevacizumab, a monoclonal antibody against vascular endothelial growth factor, has been associated with better survival when added to chemotherapy compared with paclitaxel and carboplatin [108]. The final results of a European confirmatory trial are awaiting publication.

In conclusion, to date, targeted therapy has no routine application in the first-line treatment of advanced NSCLC.

\section{Conclusion}

In advanced NSCLC, chemotherapy is recommended as firstline treatment in patients with good performance status. Treatment objectives are survival, quality of life and symptom control improvement. Cisplatin-based chemotherapy with one of the effective regimens should be used. If the second drug is new, there is no evidence for the addition of a third agent

TABLE 10 Randomised trials assessing the role of sequential chemotherapy

\begin{tabular}{|c|c|c|c|c|c|c|}
\hline Reference & Chemotherapy & Subjects $n$ & OR \% & p-value & MST & p-value \\
\hline [94] & I. Carboplatin + gemcitabine then paclitaxel & 95 & 21 & & 9 months & \\
\hline \multirow[t]{2}{*}{ [95] } & $\begin{array}{c}\text { Cisplatin + gemcitabine }+ \text { ifosfamide }(\mathrm{GIP}) \times \\
\text { three cycles; if no progression }\end{array}$ & 485 & 36 & & & \\
\hline & I. GIP & 140 & & & 9.7 months & NS \\
\hline$[96]$ & II. Gemcitabine + cisplatin [70] & 52 & 25 & & 9.7 months & \\
\hline
\end{tabular}

OR: objective response; MST: median survival time; NS: nonsignificant. 
TABLE 11 Published or oral presentations of randomised second-line studies

\begin{tabular}{|c|c|c|c|c|c|}
\hline [123] & 733 & Docetaxel & 7.6 & 2.7 & 8 \\
\hline \multirow[t]{2}{*}[122]{$^{\#}$} & 200 & Docetaxel & 12.8 & 2 & 11.5 \\
\hline & 187 & Gefitinib & 22.5 & 2 & 14 \\
\hline [121] & 73 & Docetaxel & 13.7 & $3.4^{\circ}$ & 7.1 \\
\hline [120] & 272 & Vinflunine & 4.4 & 2.3 & 6.7 \\
\hline \multirow[t]{2}{*}{ [118] } & 415 & Docetaxel & 5 & 3.2 & 7.6 \\
\hline & 414 & Oral topotecan & 5 & 2.8 & 6.9 \\
\hline \multirow[t]{2}{*}{ [119] } & 422 & Docetaxel & 12 & $2.6^{\circ}$ & 6.9 \\
\hline & 427 & Paclitaxel polyglumex & 8 & $2^{\prime}$ & 6.9 \\
\hline \multirow[t]{3}{*}{ [116] } & 125 & Docetaxel 75 & 6.7 & $2.1^{\circ}$ & 5.7 \\
\hline & 125 & Docetaxel 100 & 10.8 & $2.1^{\circ}$ & 5.5 \\
\hline & 123 & Vinorelbine/ifosfamide & 0.8 & $1.9^{\circ}$ & 5.6 \\
\hline
\end{tabular}

PFS: progression free survival. ${ }^{\#}$ : mostly Asian population; ": time to progression.

outside the context of a clinical trial. There is also no evidence that combinations with new drugs are superior to those with old drugs in terms of survival. Carboplatin may be prescribed if the patient is unable or unwilling to receive cisplatin. Nonplatinum-based regimens are indicated in patients for whom platinum-based chemotherapy is contraindicated. Cost of treatment including supportive care and complication management has to be taken into consideration when choosing a regimen. Clinical research is ongoing in order to develop customised chemotherapy.

\section{SECOND-LINE CHEMOTHERAPY}

Despite demonstrated improvements in first-line treatment, most stage IIIB/IV patients experience disease progression and $\sim 50-60 \%$ of them are fit enough to receive a second-line treatment. The availability of new active drugs allows significant improvement in survival and symptom control without a major detrimental effect on quality of life. Thus, many thoracic oncologists prescribe not only first-line chemotherapy but also usually second-line chemotherapy or EGFR TKIs followed by a third-line of treatment in a large number of patients. The current article is only concerned with cytotoxic chemotherapy and the present authors have focused on chemotherapy drugs registered or studied in the setting of second-line treatment. Other important emerging issues in second-line treatment will also be considered. Hence, as chemotherapy gains wider acceptance for use in earlier stages of NSCLC, particularly in the adjuvant and neoadjuvant setting, physicians face a growing population of high performance status patients who have relapsed after their first-line chemotherapy. The type of second-line chemotherapy after initial adjuvant or neoadjuvant treatment with a platinumbased regimen remains largely undefined. Some might consider rechallenging patients with a platinum-based combination whereas others might treat these patients according to second-line clinical guidelines. Most relapses occurring after perioperative chemotherapy and surgery are either locally advanced relapses or metastatic diseases. Some differences exist between these post-surgical relapses and the progressions occurring after the first-line nonsurgical treatment of a stage IIIB/IV patient. Therefore, patients are more likely to have a low performance status (0-1), progression is often asymptomatic and diagnosed in the post surgical follow-up, the time between the first-line of treatment and the treatment of the relapse is generally longer than in stage IIIB/IV and in most cases the dose of chemotherapy previously administered is lower than that administered in first-line treatment of a stage IIIB/IV patient. These differences might be associated with a more chemosensitive disease and might justify the treatment of these patients according to first-line guidelines. The level of evidence of such a therapeutic recommendation is scarce and studies are ongoing to answer this question [109].

\section{Which patients should receive second-line treatment?}

In stage IIIB-IV patients, response to first-line therapy is generally short lived and progression occurs an average 4-6 months after treatment is discontinued. Many of these patients continue to have a good performance status and are candidates for second-line therapy, although not all receive it. Recent studies indicate that $<50 \%$ of patients receive secondline treatment; furthermore, the characteristics of patients who receive a second-line treatment have not been well described in the literature. HENSING et al. [110] studied 230 patients with stage IIIB or IV NSCLC who received first-line therapy with carboplatin and paclitaxel. Of these patients, only $101(44 \%)$ received second-line therapy. Factors increasing the likelihood 
of second-line therapy included high performance status, female sex and nonsquamous histology, while early termination of first-line therapy decreased the likelihood of further therapy. In another study [111], sex, stage at diagnosis, performance status at the start of second-line therapy and best response to initial therapy were associated with improved survival outcome in multivariate analyses. Thus, these factors should be used to select the patients who will benefit most from second-line chemotherapy.

The impact of second-line chemotherapy has been studied in a large cohort of 4,318 patients in 19 phase III trials [112]. In the current review, the objective response rates to chemotherapeutic agents are lower than those in the first-line setting in cases of advanced NSCLC. The median intention-to-treat objective response rate was only $6.8 \%$, whereas the median disease control rate was $42.4 \%$. A median survival time of 6.6 months showed no correlation with the objective response rate $(p=0.6992)$ but, in contrast, was better associated with the disease control rate $(p=0.0129)$. This indicates that not only tumour shrinkage, but also disease stabilisation, contributes to survival benefit in the second-line setting.

The second-line treatment of NSCLC has been widely studied in the last decade and as a result, clinical practice guidelines are available and are based on randomised clinical trials. However, the setting of second-line treatment should not be limited to this well known situation. The recent introduction of targeted therapies as a potential player in the second-line has complicated the therapeutic algorithm. Clinical trials are still ongoing and the identification of predictive factors of response and survival will be a critical point in the selection of the best treatment for a given patient.

\section{Which are the recommended second-line regimens?}

The vast majority of chemotherapy guidelines recommend docetaxel or pemetrexed for stage III-IV NSCLC patients who fail first-line chemotherapy [1, 113, 114]. Promising results of phase II trials of docetaxel in previously treated patients prompted two phase III trials, which have established docetaxel as the first chemotherapeutic agent with proven benefit for patients with recurrent or refractory disease following initial chemotherapy $[115,116]$. The registration of docetaxel was based on data from these phase III trials.

In the first trial [115], docetaxel $\left(75 \mathrm{mg} \cdot \mathrm{m}^{-2}\right.$ every 3 weeks $)$ significantly prolonged median and 1-yr survival duration compared with best supportive care (median survival 7.5 versus 4.6 months; $\mathrm{p}=0.010 ; 1$-yr survival 37 versus $12 \%$ ), although the response rate was low $(5.5 \%)$. In the second study [116] the 6-months and median survival rates were similar for docetaxel and vinorelbine or ifosfamide. However, the 1-yr survival rate was significantly greater with docetaxel $\left(75 \mathrm{mg} \cdot \mathrm{m}^{-2}\right.$ ) than ifosfamide or vinorelbine (32 versus $19 \%$; $\mathrm{p}=0.025)$. In both studies docetaxel significantly improved some parameters of quality of life. Since these two pivotal studies, new potential second-line drugs were compared with the docetaxel standard of care [117-123]. With regards to the therapeutic results of the docetaxel arm of these studies, it must be emphasised that response rates and survival data were highly and significantly reproducible (table 11).
The standard 3-weekly dosing regimen has been challenged by a weekly schedule, and trials have shown that while weekly docetaxel does not result in better survival rates when compared with a 3-week docetaxel regimen, it may produce better compliance, better response rates and a lower rate of neutropenia [124-127]. Docetaxel-based combination regimens have not been found to be superior to docetaxel alone as second-line therapy and monochemotherapy remains the standard of care in this setting [128].

Pemetrexed is a multi-targeted antifolate drug. The targets of pemetrexed are the enzyme thymidylate synthase, glycinamide ribonucleotide formyl transferase and dihydrofolate reductase [129]. These enzymes are critical for the synthesis of purine nucleotides and thymidine. The initial trials with pemetrexed, mostly in patients with mesothelioma, revealed high rates of myelosuppression, mucositis and diarrhoea [130]. Later studies demonstrated that the incidence of grade three or four mucositis and diarrhoea was correlated with elevated levels of both homocysteine and methylmalonic acid [131]. These results led to the hypothesis that folic acid and vitamin B12 supplementation could lower the incidence of toxicity. This last point has been demonstrated in the pivotal mesothelioma trial [132] and folic acid and vitamin B12 supplementation is now recommended when pemetrexed is prescribed. The Food and Drug Administration approved pemetrexed for second-line NSCLC 4 yrs ago based on data from a single randomised, phase III trial comparing this new drug to docetaxel [117]. In that trial, median survival with pemetrexed $\left(500 \mathrm{mg} \cdot \mathrm{m}^{-2}\right.$ every 3 weeks) was 8.3 versus 7.9 months with docetaxel $\left(75 \mathrm{mg} \cdot \mathrm{m}^{-2}\right.$ every 3 weeks; not significantly different). Response rates and time to disease progression for both agents were comparable. The incidence of side-effects (grade three or four neutropenia, febrile neutropenia and neutropenia with infections) with pemetrexed was significantly lower than with docetaxel $(p \leqslant 0.004)$, and hospitalisations for neutropenic fever $(p<0.001)$ and other toxicities $(p=0.092)$ were also lower with pemetrexed. Furthermore an analysis of survival without grade three/four toxicity [133] suggested a benefit-to-risk profile that favours pemetrexed over docetaxel. The analysis of the impact of NSCLC histology on overall survival demonstrated clinically relevant differences in survival according to histology. Recent evidence suggests that some subtypes of NSCLC such as adenocarcinoma or large cell carcinoma benefit more from the use of pemetrexed [134] and very recently the European Medicines Agency recommended the use of pemetrexed for patients with nonsquamous histologies. These data obtained in a first-line randomised trial comparing pemetrexed and cisplatin with gemcitabine and cisplatin, were retrospectively shown in the study comparing pemetrexed with docetaxel [135]. An analysis of the impact of NSCLC histology on the treatment effect on overall survival was in favour of pemetrexed versus docetaxel for other than predominantly squamous histologies $(n=399 ; 9.3$ versus 8 months; $p=0.047)$ and was in favour of docetaxel for squamous cell carcinoma histology ( $n=172 ; 6.2$ versus 7.4 months; $p=0.018)$.

Recent phase III trials have also evaluated the use of new drugs in this setting. Oral topotecan, polyglutamated paclitaxel and vinflunine were studied in randomised trials. None of these drugs are yet approved in second-line treatment. Topotecan is 
a topoisomerase-I inhibitor. An oral form of topotecan has been developed that may offer a treatment option for patients who prefer oral to i.v. therapy. A randomised, phase III study compared the efficacy and safety of oral topotecan with i.v. docetaxel, as a second-line treatment of advanced NSCLC [118]. This study demonstrated that oral topotecan is active and tolerable in patients with previously treated advanced NSCLC. The lack of difference in the primary end-point (1-yr survival rates) indicated that oral topotecan was not inferior to docetaxel based on the prespecified $10 \%$ noninferiority margin. However, the docetaxel treatment group had a higher survival rate than the oral topotecan treatment group $(\mathrm{p}=0.057)$. Median time to progression favoured the docetaxel group, with an absolute difference of 1.8 weeks $(p=0.02)$. With respect to adverse events, the two treatments offered similar risk profiles, although each produced a different set of toxicities. Grade three/four neutropenia occurred more frequently with docetaxel, whereas grade three/four anaemia and grade three thrombocytopenia were more frequent with topotecan. Nausea, diarrhoea and vomiting were more frequent in the topotecan group, whereas alopecia, neuropathy and fever were more frequent in the docetaxel group. Overall, both treatments showed a progressive worsening of the quality of life symptom scores. This large trial (829 patients), demonstrated the activity of topotecan in NSCLC; however, this drug appeared globally slightly inferior to docetaxel. Oral topotecan would have provided an option for patients who desire an oral treatment after relapse, this option is probably unrealistic given the fact that EGFR TKIs are also oral treatments but with a sharply lower toxicity profile.

Paclitaxel, the other available taxane, has also demonstrated potential activity in the second-line setting. Phase II studies [126-142] and a follow-up study of all the patients who received paclitaxel as second-line chemotherapy after a randomised phase III trial [143] have demonstrated the activity of the single agent paclitaxel. The equivalent of docetaxel and pemetrexed was evaluated in one small randomised phase II study which found no statistically significant difference in terms of response rate (14 versus 3\%) and median survival (105 versus 184 days) [144].

BONOMI et al. [119] recently reported a second-line phase III trial that compared docetaxel with paclitaxel poliglumex in 849 patients. Paclitaxel poliglumex, a macromolecule drug conjugate linking paclitaxel to polyglutamic acid, reduces systemic exposure to peak concentrations of free paclitaxel. Patients received 175 or $210 \mathrm{mg} \cdot \mathrm{m}^{-2}$ of paclitaxel poliglumex or $75 \mathrm{mg} \cdot \mathrm{m}^{-2}$ of docetaxel. The study enrolled 849 previously treated NSCLC patients with advanced disease. Median survival was 6.9 months in both arms, $(p=0.257), 1-y r$ survival was $25 \%$ for paclitaxel polyglumex and $29 \%$ for docetaxel $(\mathrm{p}=0.134)$, and time to progression (median: paclitaxel polyglumex 2 months and docetaxel 2.6 months; $\mathrm{p}=0.075$ ) were similar between treatment arms. Paclitaxel poliglumex was associated with significantly less grade three or four neutropenia $(p<0.001)$ and febrile neutropenia $(p=0.006)$. Grade three or four neuropathy $(p<0.001)$ was more common in the paclitaxel polyglumex arm. Patients receiving paclitaxel polyglumex had less alopecia and did not receive routine premedications. Paclitaxel poliglumex and docetaxel produced similar survival results but had different toxicity profiles.
Compared with docetaxel, paclitaxel poliglumex patients had less alopecia and less febrile neutropenia, shorter infusion times and a higher rate of the elimination of routine use of medications to prevent hypersensitivity reactions.

Vinorelbine is a second-generation semi-synthetic vinca alkaloid agent. Phase II studies have studied vinorelbine in combination with other agents such as gemcitabine, cisplatin [145-150] and mitomycin C [151]. These second-line studies have shown results consistent with those previously demonstrated with other drugs in phase II. Notably a standard reproducible activity and a manageable tolerance profile has been demonstrated. However, disappointing results shown in a phase III comparison of docetaxel versus vinorelbine or ifosfamide [116] have limited the use of this agent in routine clinical practice. In the same generation of drugs vinflunine is a novel tubulin-targeted agent obtained by semi-synthesis. The actions of vinflunine on microtubules produce effects on mitotic spindle functions leading to modifications of cell cycle progression and cell killing [152]. Vinflunine prevents microtubule assembly during mitosis [153-155]. The affinity profile of vinflunine shows features which suggest that it will have greater effects on mitotic rather than axonal tubulin and so will cause less neurotoxicity [156]. Vinflunine showed antitumour activity in a multicentre, single-arm, phase II trial in patients with advanced NSCLC previously treated with a platinumbased regimen [157]. In total, 63 patients were included, the response rate was $7.9 \%$, median progression free survival was 2.6 months (95\% confidence interval 1.4-3.8), and median survival was 7.0 months. Grades three to four neutropenia was reported in $50 \%$ of patients; febrile neutropenia was observed in two patients $(3.2 \%)$; grades three to four myalgia and grade three constipation were experienced by $10(15.9 \%)$ and six $(9.5 \%)$ patients, respectively. Constipation was manageable, noncumulative and could be prevented with laxative prophylaxis. The encouraging results from this phase II study led to a phase III trial comparing vinflunine to docetaxel. In total, 547 stage IIIB/IV pre-treated patients were treated with vinflunine $320 \mathrm{mg} \cdot \mathrm{m}^{-2}$ (272 patients) or docetaxel $75 \mathrm{mg} \cdot \mathrm{m}^{-2} \quad(275$ patients) [120]. Response rates were $<5 \%$ in both arms and overall survival and progression free survival were similar. The toxicity profile seemed to disfavour vinflunine, with pretty comparable haematological toxicity but a little more fatigue, abdominal pain and constipation. Overall, vinflunine emerged as a reasonable alternative to taxotere in this setting, but there was no obvious reason to recommend it over the already existing drugs.

\section{How to select a second-line regimen}

A short list of agents is now available in the second-line setting; new agents are eagerly awaited, however, no dramatic breakthroughs have appeared from the existing published or ongoing trials. The available agents appear to have similar efficacies in terms of response and overall survival, but also have significantly different toxicity profiles. Currently, the selection of a second-line agent depends on a number of factors, including patient preference, physician preference, performance status and patient comorbidities, smoking history, response to first-line chemotherapy, toxicities related to first-line chemotherapy and, according to recent studies $[111,134]$, the histological type of the tumour. Given the 
incurable nature of advanced NSCLC and the modest survival seen in the second-line setting, patient convenience and preference should be considered first when selecting a second-line agent [158]. In addition to patient preference, performance status and comorbidities may also impact the selection of second-line therapies. Pemetrexed is contraindicated in patients with renal insufficiency (glomerular filtration rate $<40 \mathrm{~mL} \cdot \mathrm{min}^{-1}$ ). Docetaxel may be given to patients with renal insufficiency but requires dose adjustments for those with hepatic impairment. Docetaxel has a higher rate of neurotoxicity than pemetrexed. Pemetrexed or an EGFR TKI may be preferable in patients with diabetic neuropathy or residual neuropathy from first-line therapy.

Nonsmokers with lung cancer are at high probability to respond to EGFR TKIs, this last point is critical in the selection of a second-line treatment. Response to first-line treatment appears to be a prognostic factor in patients receiving secondline treatment, furthermore nonresponding patients are often more likely to be treated with an EGFR TKI instead of chemotherapy. The emerging role of histology has been recently shown either for adenocarcinomas which are more likely to benefit to EGFR TKIs, and for large cell carcinomas and adenocarcinomas which are more likely to respond to pemetrexed whereas epidermoid carcinomas benefit more from docetaxel.

It is highly probable that in the future the use of molecular markers will assist the therapeutic decision-making. Research efforts continue to focus on identifying molecular markers and corresponding clinical features that will allow physicians to individualise patients' therapy. Furthermore a better understanding of prognostic factors in the second-line setting may allow clinicians to better select patients for second-line therapy and lead to better-designed second-line trials. Several new agents have shown activity in phase III trials; however, their efficacy and toxicity profile is not superior to that of existing agents and this raises doubts on their regulatory approval in the future. New drugs, such as enzastaurin, bortezomib, vorinostat and epidermal growth factor receptor or vascular epidermal growth factor targeted therapies administered alone or combined with either pemetrexed or docetaxel are currently being tested in clinical trials. These drugs may be integrated into second-line therapy as single agents or in combination with current agents in the future.

\section{REFERENCES}

1 European Lung Cancer Working Party (ELCWP), Sculier J-P. Traitement des cancers bronchiques non à petites cellules: maladies avancées (métastatiques). Les recommandations de pratique clinique de l'European Lung Cancer Working Party [Treatment of nonsmall cell lung cancer: advanced (metastatic) disease. Guidelines of clinical practice made by the European Lung Cancer Working Party]. Rev Med Brux 2007; 28: 495-511.

2 Alexopoulos A, Alard S, Berghmans T, et al. European Lung Cancer Working Party clinical practice guidelines. Non-small cell lung cancer: III. Metastatic disease. Hospital Chronicles 2006; 1: 169-185.
3 Cormier Y, Bergeron D, La Forge J, et al. Benefits of polychemotherapy in advanced non-small-cell bronchogenic carcinoma. Cancer 1982; 50: 845-849.

4 Rapp E, Pater JL, Willan A, et al. Chemotherapy can prolong survival in patients with advanced non-smallcell lung cancer-report of a Canadian multicenter randomized trial. J Clin Oncol 1988; 6: 633-641.

5 Ganz PA, Figlin RA, Haskell CM, La Soto N, Siau J. Supportive care versus supportive care and combination chemotherapy in metastatic non-small cell lung cancer. Does chemotherapy make a difference? Cancer 1989; 63: 1271-1278.

6 Woods RL, Williams CJ, Levi J, et al. A randomised trial of cisplatin and vindesine versus supportive care only in advanced non-small cell lung cancer. Br J Cancer 1990; 61: 608-611.

7 Kaasa S, Lund E, Thorud E, Hatlevoll R, Host H. Symptomatic treatment versus combination chemotherapy for patients with extensive non-small cell lung cancer. Cancer 1991; 67: 2443-2447.

8 Quoix E, Dietemann A, Charbonneau J, et al. La chimiothérapie comportant du cisplatine est-elle utile dans le cancer bronchique non microcellulaire au stade IV? Résultats d'une étude randomisée [Is chemotherapy with cisplatine useful in bronchial nonsmall cell cancer at stage IV? The results of a randomised study]. Bull Cancer 1991; 78: 341-346.

9 Cellerino R, Tummarello D, Guidi F, et al. A randomized trial of alternating chemotherapy versus best supportive care in advanced non-small-cell lung cancer. J Clin Oncol 1991; 9: 1453-1461.

10 Leung WT, Shiu WC, Pang JC, et al. Combined chemotherapy and radiotherapy versus best supportive care in the treatment of inoperable non-small-cell lung cancer. Oncology 1992; 49: 321-326.

11 Cartei G, Cartei F, Cantone A, et al. Cisplatincyclophosphamide-mitomycin combination chemotherapy with supportive care versus supportive care alone for treatment of metastatic non-small-cell lung cancer. J Natl Cancer Inst 1993; 85: 794-800.

12 Helsing M, Bergman B, Thaning L, Hero U. Quality of life and survival in patients with advanced non-small cell lung cancer receiving supportive care plus chemotherapy with carboplatin and etoposide or supportive care only. A multicentre randomised phase III trial. Joint Lung Cancer Study Group. Eur J Cancer 1998; 34: 1036-1044.

13 Thongprasert S, Sanguanmitra P, Juthapan W, Clinch J. Relationship between quality of life and clinical outcomes in advanced non-small cell lung cancer: best supportive care (BSC) versus BSC plus chemotherapy. Lung Cancer 1999; 24: 17-24.

14 Cullen $\mathrm{MH}$, Billingham LJ, Woodroffe CM, et al. Mitomycin, ifosfamide, and cisplatin in unresectable non-small-cell lung cancer: effects on survival and quality of life. J Clin Oncol 1999; 17: 3188-3194.

15 Spiro SG, Rudd RM, Souhami RL, et al. Chemotherapy versus supportive care in advanced non-small cell lung cancer: improved survival without detriment to quality of life. Thorax 2004; 59: 828-836.

16 The Elderly Lung Cancer Vinorelbine Italian Study Group. Effects of vinorelbine on quality of life and 
survival of elderly patients with advanced non-small-cell lung cancer. J Natl Cancer Inst 1999; 91: 66-72.

17 Ranson M, Davidson N, Nicolson M, et al. Randomized trial of paclitaxel plus supportive care versus supportive care for patients with advanced non-small-cell lung cancer. J Natl Cancer Inst 2000; 92: 1074-1080.

18 Anderson H, Hopwood P, Stephens RJ, et al. Gemcitabine plus best supportive care (BSC) vs BSC in inoperable nonsmall cell lung cancer-a randomized trial with quality of life as the primary outcome. UK NSCLC Gemcitabine Group. Non-small cell lung cancer. Br J Cancer 2000; 83: 447-453.

19 Roszkowski K, Pluzanska A, Krzakowski M, et al. A multicenter, randomized, phase III study of docetaxel plus best supportive care versus best supportive care in chemotherapy-naive patients with metastatic or nonresectable localized non-small cell lung cancer (NSCLC). Lung Cancer 2000; 27: 145-157.

20 Souquet PJ, Chauvin F, Boissel JP, et al. Polychemotherapy in advanced non small cell lung cancer: a meta-analysis. Lancet 1993; 342: 19-21.

21 Grilli R, Oxman AD, Julian JA. Chemotherapy for advanced non-small-cell lung cancer: how much benefit is enough? J Clin Oncol 1993; 11: 1866-1872.

22 Marino P, Pampallona S, Preatoni A, Cantoni A, Invernizzi F. Chemotherapy vs supportive care in advanced non-small-cell lung cancer. Results of a metaanalysis of the literature. Chest 1994; 106: 861-865.

23 Non-small Cell Lung Cancer Collaborative Group. Chemotherapy in non-small cell lung cancer: a metaanalysis using updated data on individual patients from 52 randomised clinical trials. BMJ 1995; 311: 899-909.

24 Sculier JP, Berghmans T, Castaigne A, et al. Best supportive care or chemotherapy for stage IV non small cell lung cancer. In: Van Houtte P, Klastersky J, Rocmans $\mathrm{P}$, eds. Progress and perspectives in lung cancer. Berlin, Springer Verlag, 1999; pp. 199-207.

25 Socinski MA, Morris DE, Masters GA, Lilenbaum R. Chemotherapeutic management of stage IV non-small cell lung cancer. Chest 2003; 123: Suppl. 1, 226S-243S.

26 Jaakkimainen L, Goodwin PJ, Pater J, Warde P, Murray N, Rapp E. Counting the costs of chemotherapy in a National Cancer Institute of Canada randomized trial in nonsmall-cell lung cancer. J Clin Oncol 1990; 8: 1301-1309.

27 Donnadieu N, Paesmans M, Sculier JP. Chimiothérapie des cancers bronchiques non à petites cellules. Métaanalyse de la littérature en fonction de l'extension de la maladie [Chemotherapy of nonsmall cell bronchial cancers. Literature according to a meta-analysis; extension of the disease]. Rev Mal Respir 1991; 8: 197-204.

28 Meert AP, Berghmans T, Branle F, et al. Phase II and III studies with new drugs for non-small cell lung cancer: a systematic review of the literature with a methodology quality assessment. Anticancer Res 1999; 19: 4379-4390.

29 Depierre A, Lagrange JL, Theobald S, et al. Standards, options and recommendations for the management of non-small cell lung carcinoma patients. Br J Cancer 2003; 89: Suppl. 1, S35-S49.

30 Socinski MA, Crowell R, Hensing TE, et al. Treatment of non-small cell lung cancer, stage IV: ACCP evidence-based clinical practice guidelines (2nd Edn). Chest 2007; 132: Suppl. 3, 277S-289S.

31 Pfister DG, Johnson DH, Azzoli CG, et al. American Society of Clinical Oncology treatment of unresectable non-small-cell lung cancer guideline: update 2003. J Clin Oncol 2004; 22: 330-353.

32 Sculier JP. Treatment of thoracic malignancy - results of meta-analyses. Rev Mal Respir 2005; 22: 8S81-8S89.

33 Marino P, Preatoni A, Cantoni A, Buccheri G. Singleagent chemotherapy versus combination chemotherapy in advanced non-small cell lung cancer: a quality and metaanalysis study. Lung Cancer 1995; 13: 1-12.

34 Lilenbaum RC, Langenberg P, Dickersin K. Single agent versus combination chemotherapy in patients with advanced nonsmall cell lung carcinoma: a meta-analysis of response, toxicity, and survival. Cancer 1998; 82: 116-126.

35 Delbaldo C, Michiels S, Syz N, Soria JC, Le Chevalier T, Pignon JP. Benefits of adding a drug to a single-agent or a 2agent chemotherapy regimen in advanced non-small-cell lung cancer: a meta-analysis. JAMA 2004; 292: 470-484.

36 Hotta K, Matsuo K, Ueoka H, Kiura K, Tabata M, Tanimoto M. Addition of platinum compounds to a new agent in patients with advanced non-small-cell lung cancer: a literature based meta-analysis of randomised trials. Ann Oncol 2004; 15: 1782-1789.

37 Sculier JP, Ghisdal L, Berghmans T, et al. The role of mitomycin in the treatment of non-small cell lung cancer: a systematic review with meta-analysis of the literature. Br J Cancer 2001; 84: 1150-1155.

38 Le Chevalier T, Scagliotti G, Natale R, et al. Efficacy of gemcitabine plus platinum chemotherapy compared with other platinum containing regimens in advanced nonsmall-cell lung cancer: a meta-analysis of survival outcomes. Lung Cancer 2005; 47: 69-80.

39 Sanchez Lerma B, Penuelas Sanchez I, Guillen Grima F. Docetaxel en combinacion con cisplatino para el tratamiento en primera linea del cancer del pulmon no microcitico metastasico o localmente avanzado: metaanalisis de ensayos clinicos aleatorizados y controlados [Docetaxel in combination with cisplatin for the treatment of locally advanced metastatic nonsmall cell lung cancer: meta-analysis of randomised and controlled clinical tests]. Med Clin (Barc) 2004; 122: 281-287.

40 Douillard JY, Laporte S, Fossella F, et al. Comparison of docetaxel- and vinca alkaloid-based chemotherapy in the first-line treatment of advanced non-small cell lung cancer: a meta-analysis of seven randomized clinical trials. J Thorac Oncol 2007; 2: 939-946.

41 Chu Q, Vincent M, Logan D, Mackay JA, Evans WK. Taxanes as first-line therapy for advanced non-small cell lung cancer: a systematic review and practice guideline. Lung Cancer 2005; 50: 355-374.

42 Baggstrom MQ, Stinchcombe TE, Fried DB, Poole C, Hensing TA, Socinski MA. Third-generation chemotherapy agents in the treatment of advanced non-small cell lung cancer: a meta-analysis. J Thorac Oncol 2007; 2: 845-853.

43 Tanvetyanon T, Soares HP, Djulbegovic B, Jacobsen PB, Bepler G. A systematic review of quality of life associated with standard chemotherapy regimens for advanced nonsmall cell lung cancer. J Thorac Oncol 2007; 2: 1091-1097. 
44 Gralla RJ, Casper ES, Kelsen DP, et al. Cisplatin and vindesine combination chemotherapy for advanced carcinoma of the lung: a randomized trial investigating two dosage schedules. Ann Intern Med 1981; 95: 414-420.

45 Klastersky J, Sculier JP, Ravez P, et al. A randomized study comparing a high and a standard dose of cisplatin in combination with etoposide in the treatment of advanced non-small-cell lung carcinoma. J Clin Oncol 1986; 4: 1780-1786.

46 Shinkai T, Saijo N, Eguchi K, et al. Cisplatin and vindesine combination chemotherapy for non-small cell lung cancer: a randomized trial comparing two dosages of cisplatin. Jpn J Cancer Res 1986; 77: 782-789.

47 Gandara DR, Crowley J, Livingston RB, et al. Evaluation of cisplatin intensity in metastatic non-small-cell lung cancer: a phase III study of the Southwest Oncology Group. J Clin Oncol 1993; 11: 873-878.

48 Sculier JP, Lafitte JJ, Paesmans M, et al. Phase III randomized trial comparing moderate-dose cisplatin to combined cisplatin and carboplatin in addition to mitomycin and ifosfamide in patients with stage IV non-small-cell lung cancer. Br J Cancer 2000; 83: 1128-1135.

49 Sculier JP, Klastersky J, Giner V, et al. Phase II randomized trial comparing high-dose cisplatin with moderate-dose cisplatin and carboplatin in patients with advanced non-small-cell lung cancer. European Lung Cancer Working Party. J Clin Oncol 1994; 12: 353-359.

50 Klastersky J, Sculier JP, Lacroix H, et al. A randomized study comparing cisplatin or carboplatin with etoposide in patients with advanced non-small-cell lung cancer: European Organization for Research and Treatment of Cancer Protocol 07861. J Clin Oncol 1990; 8: 1556-1562.

51 Comella P, Scoppa G, Daponte A, et al. Alternated approach with local irradiation and combination chemotherapy including cisplatin or carboplatin plus epirubicin and etoposide in intermediate stage non-small cell lung cancer. Cancer 1994; 74: 1874-1881.

52 Jelic S, Mitrovic L, Radosavljevic D, et al. Survival advantage for carboplatin substituting cisplatin in combination with vindesine and mitomycin C for stage IIIB and IV squamous-cell bronchogenic carcinoma: a randomized phase III study. Lung Cancer 2001; 34: 1-13.

53 Schiller JH, Harrington D, Belani CP, et al. Comparison of four chemotherapy regimens for advanced non-small-cell lung cancer. N Engl J Med 2002; 346: 92-98.

54 Rosell R, Gatzemeier U, Betticher DC, et al. Phase III randomised trial comparing paclitaxel/carboplatin with paclitaxel/cisplatin in patients with advanced non-smallcell lung cancer: a cooperative multinational trial. Ann Oncol 2002; 13: 1539-1549.

55 Mazzanti P, Massacesi C, Rocchi MB, et al. Randomized, multicenter, phase II study of gemcitabine plus cisplatin versus gemcitabine plus carboplatin in patients with advanced non-small cell lung cancer. Lung Cancer 2003; 41: 81-89.

56 Fossella F, Pereira JR, von Pawel J, et al. Randomized, multinational, phase III study of docetaxel plus platinum combinations versus vinorelbine plus cisplatin for advanced non-small-cell lung cancer: the TAX 326 study group. J Clin Oncol 2003; 21: 3016-3024.
57 Zatloukal P, Petruzelka L, Zemanova M, et al. Gemcitabine plus cisplatin vs. gemcitabine plus carboplatin in stage IIIb and IV non-small cell lung cancer: a phase III randomized trial. Lung Cancer 2003; 41: 321-331.

58 Paccagnella A, Favaretto A, Oniga F, et al. Cisplatin versus carboplatin in combination with mitomycin and vinblastine in advanced non small cell lung cancer. A multicenter, randomized phase III trial. Lung Cancer 2004; 43: 83-91.

59 Chen YM, Perng RP, Tsai CM, Whang-Peng J. A phase II study of paclitaxel plus carboplatin or cisplatin against chemo-naive inoperable non-small cell lung cancer in the elderly. J Thorac Oncol 2006; 1: 141-145.

60 Hotta K, Matsuo K, Ueoka H, Kiura K, Tabata M, Tanimoto M. Meta-analysis of randomized clinical trials comparing cisplatin to carboplatin in patients with advanced non-small-cell lung cancer. J Clin Oncol 2004; 22: 3852-3859.

61 Ardizzoni A, Boni L, Tiseo M, et al. Cisplatin- versus carboplatin-based chemotherapy in first-line treatment of advanced non-small-cell lung cancer: an individual patient data meta-analysis. I Natl Cancer Inst 2007; 99: 847-857.

62 Jiang J, Liang X, Zhou X, Huang R, Chu Z. A metaanalysis of randomized controlled trials comparing carboplatin-based to cisplatin-based chemotherapy in advanced non-small cell lung cancer. Lung Cancer 2007; 57: 348-358.

63 Smith IE, O'Brien ME, Talbot DC, et al. Duration of chemotherapy in advanced non-small-cell lung cancer: a randomized trial of three versus six courses of mitomycin, vinblastine and cisplatin. J Clin Oncol 2001; 19: 1336-1343.

64 von Plessen C, Bergman B, Andresen O, et al. Palliative chemotherapy beyond three courses conveys no survival or consistent quality-of-life benefits in advanced nonsmall-cell lung cancer. Br J Cancer 2006; 95: 966-973.

65 Park JO, Kim SW, Ahn JS, et al. Phase III trial of two versus four additional cycles in patients who are nonprogressive after two cycles of platinum-based chemotherapy in non small-cell lung cancer. J Clin Oncol 2007; 25: 5233-5239.

66 Socinski MA, Schell MJ, Peterman A, et al. Phase III trial comparing a defined duration of therapy versus continuous therapy followed by second-line therapy in advanced-stage IIIB/IV non-small-cell lung cancer. J Clin Oncol 2002; 20: 1335-1343.

67 Belani CP, Barstis J, Perry MC, et al. Multicenter, randomized trial for stage IIIB or IV non-small-cell lung cancer using weekly paclitaxel and carboplatin followed by maintenance weekly paclitaxel or observation. J Clin Oncol 2003; 21: 2933-2939.

68 Westeel V, Quoix E, Moro-Sibilot D, et al. Randomized study of maintenance vinorelbine in responders with advanced non-small-cell lung cancer. J Natl Cancer Inst 2005; 97: 499-506.

69 Brodowicz T, Krzakowski M, Zwitter M, et al. Cisplatin and gemcitabine first-line chemotherapy followed by maintenance gemcitabine or best supportive care in advanced non-small cell lung cancer: a phase III trial. Lung Cancer 2006; 52: 155-163.

70 Novello S, Bruzzi P, Barone C, et al. Phase III study in stage IV non-small-cell lung cancer patients treated with 
two courses of cisplatin/gemcitabine followed by a randomization to three additional courses of the same combination or gemcitabine alone. Ann Oncol 2007; 18: 903-908.

71 Georgoulias V, Papadakis E, Alexopoulos A, et al. Platinum-based and non-platinum-based chemotherapy in advanced non-small-cell lung cancer: a randomised multicentre trial. Lancet 2001; 357: 1478-1484.

72 Sculier JP, Lafitte JJ, Lecomte J, et al. A three-arm phase III randomised trial comparing combinations of platinum derivatives, ifosfamide and/or gemcitabine in stage IV non-small-cell lung cancer. Ann Oncol 2002; 13: 874-882.

73 Kosmidis P, Mylonakis N, Nicolaides C, et al. Paclitaxel plus carboplatin versus gemcitabine plus paclitaxel in advanced non-small-cell lung cancer: a phase III randomized trial. J Clin Oncol 2002; 20: 3578-585.

74 Greco FA, Gray JR Jr, Thompson DS, et al. Prospective randomized study of four novel chemotherapy regimens in patients with advanced nonsmall cell lung carcinoma: a minnie pearl cancer research network trial. Cancer 2002; 95: 1279-1285.

75 Chen YM, Perng RP, Lee YC, et al. Paclitaxel plus carboplatin, compared with paclitaxel plus gemcitabine, shows similar efficacy while more cost-effective: a randomized phase II study of combination chemotherapy against inoperable non-small-cell lung cancer previously untreated. Ann Oncol 2002; 13: 108-115.

76 Gebbia V, Galetta D, Caruso M, et al. Gemcitabine and cisplatin versus vinorelbine and cisplatin versus ifosfamide+gemcitabine followed by vinorelbine and cisplatin versus vinorelbine and cisplatin followed by ifosfamide and gemcitabine in stage IIIB-IV non small cell lung carcinoma: a prospective randomized phase III trial of the Gruppo Oncologico Italia Meridionale. Lung Cancer 2003; 39: 179-189.

77 Gridelli C, Gallo C, Shepherd FA, et al. Gemcitabine plus vinorelbine compared with cisplatin plus vinorelbine or cisplatin plus gemcitabine for advanced non-small-cell lung cancer: a phase III trial of the Italian GEMVIN Investigators and the National Cancer Institute of Canada Clinical Trials Group. J Clin Oncol 2003; 21: 3025-3034.

78 Alberola V, Camps C, Provencio M, et al. Cisplatin plus gemcitabine versus a cisplatin-based triplet versus nonplatinum sequential doublets in advanced non-small-cell lung cancer: a Spanish Lung Cancer Group phase III randomized trial. J Clin Oncol 2003; 21: 3207-3213.

79 Smit EF, van Meerbeeck JP, Lianes P, et al. Three-arm randomized study of two cisplatin-based regimens and paclitaxel plus gemcitabine in advanced non-small-cell lung cancer: a phase III trial of the European Organization for Research and Treatment of Cancer Lung Cancer Group-EORTC 08975. J Clin Oncol 2003; 21: 3909-3917.

80 Wachters FM, Van Putten JW, Kramer H, et al. First-line gemcitabine with cisplatin or epirubicin in advanced non-small-cell lung cancer: a phase III trial. Br J Cancer 2003; 89: 1192-1199.

81 Yamamoto N, Fukuoka M, Negoro SI, et al. Randomised phase II study of docetaxel/cisplatin vs docetaxel/ irinotecan in advanced non-small-cell lung cancer: a
West Japan Thoracic Oncology Group Study (WJTOG9803). Br J Cancer 2004; 90: 87-92.

82 Laack E, Dickgreber N, Muller T, et al. Randomized phase III study of gemcitabine and vinorelbine versus gemcitabine, vinorelbine, and cisplatin in the treatment of advanced non-small-cell lung cancer: from the German and Swiss Lung Cancer Study Group. J Clin Oncol 2004; 22: 2348-2356.

83 Stathopoulos GP, Veslemes M, Georgatou N, et al. Frontline paclitaxel-vinorelbine versus paclitaxel-carboplatin in patients with advanced non-small-cell lung cancer: a randomized phase III trial. Ann Oncol 2004; 15: 1048-1055.

84 Lilenbaum RC, Chen CS, Chidiac T, et al. Phase II randomized trial of vinorelbine and gemcitabine versus carboplatin and paclitaxel in advanced non-small-cell lung cancer. Ann Oncol 2005; 16: 97-101.

85 Chen YM, Perng RP, Shih JF, Tsai CM, Whang-Peng J. A randomized phase II study of vinorelbine plus gemcitabine with/without cisplatin against inoperable nonsmall-cell lung cancer previously untreated. Lung Cancer 2005; 47: 373-380.

86 Pujol JL, Breton JL, Gervais R, et al. Gemcitabine-docetaxel versus cisplatin-vinorelbine in advanced or metastatic nonsmall-cell lung cancer: a phase III study addressing the case for cisplatin. Ann Oncol 2005; 16: 602-610.

87 Georgoulias V, Ardavanis A, Tsiafaki X, et al. Vinorelbine plus cisplatin versus docetaxel plus gemcitabine in advanced non-small-cell lung cancer: a phase III randomized trial. J Clin Oncol 2005; 23: 2937-2945.

88 Tan EH, Szczesna A, Krzakowski M, et al. Randomized study of vinorelbine-gemcitabine versus vinorelbinecarboplatin in patients with advanced non-small cell lung cancer. Lung Cancer 2005; 49: 233-240.

89 Katagami N, Takiguchi Y, Yoshimori K, et al. Docetaxel in combination with either cisplatin or gemcitabine in unresectable non-small cell lung carcinoma: a randomized phase II study by the Japan Lung Cancer Cooperative Clinical Study Group. J Thorac Oncol 2006; 1: 447-453.

90 Yamamoto N, Nakagawa K, Uejima H, et al. Randomized phase II study of carboplatin/gemcitabine versus vinorelbine/gemcitabine in patients with advanced nonsmall cell lung cancer: West Japan Thoracic Oncology Group (WJTOG) 0104 1. Cancer 2006; 107: 599-605.

91 Barlesi F, Pujol JL. Combination of chemotherapy without platinum compounds in the treatment of advanced non-small cell lung cancer: a systematic review of phase III trials. Lung Cancer 2005; 49: 289-298.

92 D'Addario G, Pintilie M, Leighl NB, Feld R, Cerny T, Shepherd FA. Platinum-based versus non-platinum-based chemotherapy in advanced non-small-cell lung cancer: a meta-analysis of the published piterature. J Clin Oncol 2005; 23: 2926-2936.

93 Pujol JL, Barlesi F, Daures JP. Should chemotherapy combinations for advanced non-small cell lung cancer be platinum-based? A meta-analysis of phase III randomized trials. Lung Cancer 2006; 51: 335-345.

94 Edelman MJ, Clark JI, Chansky K, et al. Randomized phase II trial of sequential chemotherapy in advanced non-small cell lung cancer (SWOG 9806): carboplatin/gemcitabine 
followed by paclitaxel or cisplatin/vinorelbine followed by docetaxel. Clin Cancer Res 2004; 10: 5022-5026.

95 Sculier J, Lafitte J, Lecomte J, et al. A phase III randomised trial comparing sequential chemotherapy using cisplatinbased regimen and paclitaxel to cisplatin-based chemotherapy alone in advanced non-small-cell lung cancer. Ann Oncol 2007; 18: 1037-1042.

96 Grigorescu A, Ciuleanu T, Firoiu E, Muresan DR, Teodorescu G, Basson BR. A randomized phase II trial of sequential gemcitabine plus vinorelbine followed by gemcitabine plus ifosfamide versus gemcitabine plus cisplatin in the treatment of chemo-naive patients with stages III and IV non-small cell lung cancer (NSCLC). Lung Cancer 2007; 57: 168-174.

97 Olaussen KA, Dunant A, Fouret P, et al. DNA repair by ERCC1 in non-small-cell lung cancer and cisplatin-based adjuvant chemotherapy. N Engl J Med 2006; 355: 983-991.

98 Filipits M, Pirker R, Dunant A, et al. Cell cycle regulators and outcome of adjuvant cisplatin-based chemotherapy in completely resected non-small-cell lung cancer: the International Adjuvant Lung Cancer Trial Biologic Program. J Clin Oncol 2007; 25: 2735-2740.

99 Tsao MS, viel-Ronen S, Ding K, et al. Prognostic and predictive importance of p53 and RAS for adjuvant chemotherapy in non small-cell lung cancer. J Clin Oncol 2007; 25: 5240-5247.

100 Zheng Z, Chen T, Li X, Haura E, Sharma A, Bepler G. DNA synthesis and repair genes RRM1 and ERCC1 in lung cancer. N Engl J Med 2007; 356: 800-808.

101 Ceppi P, Volante M, Novello S, et al. ERCC1 and RRM1 gene expressions but not EGFR are predictive of shorter survival in advanced non-small-cell lung cancer treated with cisplatin and gemcitabine. Ann Oncol 2006; 17: 1818-1825.

102 Simon G, Sharma A, Li X, et al. Feasibility and efficacy of molecular analysis-directed individualized therapy in advanced non-small-cell lung cancer. J Clin Oncol 2007; 25: 2741-2746.

103 Cobo M, Isla D, Massuti B, et al. Customizing cisplatin based on quantitative excision repair cross-complementing 1 mRNA expression: a phase III trial in non-small-cell lung cancer. J Clin Oncol 2007; 25: 2747-2754.

104 Giaccone G, Herbst RS, Manegold C, et al. Gefitinib in combination with gemcitabine and cisplatin in advanced non-small-cell lung cancer: a phase III trial - INTACT 1. J Clin Oncol 2004; 22: 777-784.

105 Herbst RS, Giaccone G, Schiller JH, et al. Gefitinib in combination with paclitaxel and carboplatin in advanced non-small-cell lung cancer: a phase III trial - INTACT 2. J Clin Oncol 2004; 22: 785-794.

106 Herbst RS, Prager D, Hermann R, et al. TRIBUTE: a phase III trial of erlotinib hydrochloride (OSI-774) combined with carboplatin and paclitaxel chemotherapy in advanced non-small-cell lung cancer. J Clin Oncol 2005; 23: 5892-5899.

107 Lilenbaum R, Axelrod R, Thomas S, et al. Randomized phase II trial of erlotinib or standard chemotherapy in patients with advanced non-small-cell lung cancer and a performance status of 2. J Clin Oncol 2008; 26: 863-869.
108 Sandler A, Gray R, Perry MC, et al. Paclitaxel-carboplatin alone or with bevacizumab for non-small-cell lung cancer. N Engl J Med 2006; 355: 2542-2550.

109 Moro-Sibilot D, Barlesi F, Timsit JF, et al. How to treat the relapse of NSCLC after surgery and chemotherapy? IFTC 0702 randomized phase III study. Rev Mal Respir 2008; 25: 91-96.

110 Hensing TA, Schell MJ, Lee JH, et al. Factors associated with the likelihood of receiving second line therapy for advanced non-small cell lung cancer. Lung Cancer 2005; 47: 253-259.

111 Weiss GJ, Rosell R, Fossella F, et al. The impact of induction chemotherapy on the outcome of second-line therapy with pemetrexed or docetaxel in patients with advanced non-small-cell lung cancer. Ann Oncol 2007; 18: 453-460.

112 Hotta K, Fujiwara Y, Kiura K, et al. Relationship between response and survival in more than 50,000 patients with advanced non-small cell lung cancer treated with systemic chemotherapy in 143 phase III trials. J Thorac Oncol 2007; 2: 402-407.

113 D'Addario G, Felip E, ESMO Guidelines Working Group. Non-small-cell lung cancer: ESMO Clinical Recommendations for diagnosis, treatment and follow-up. Ann Oncol 2007; 18: Suppl. 2, ii30-ii31.

114 Noble J, Ellis PM, Mackay JA, Evans WK, Lung Cancer Disease Site Group of Cancer Care Ontario's Program in Evidence-based Care. Second-line or subsequent systemic therapy for recurrent or progressive non-small cell lung cancer: a systematic review and practice guideline. J Thorac Oncol 2006; 1: 1042-1058.

115 Shepherd FA, Dancey J, Ramlau R, et al. Prospective randomized trial of docetaxel versus best supportive care in patients with non-small-cell lung cancer previously treated with platinum-based chemotherapy. J Clin Oncol 2000; 18: 2095-2103.

116 Fossella FV, DeVore R, Kerr RN, et al. Randomized phase III trial of docetaxel versus vinorelbine or ifosfamide in patients with advanced non-small-cell lung cancer previously treated with platinum-containing chemotherapy regimens. The TAX 320 Non-Small Cell Lung Cancer Study Group. J Clin Oncol 2000; 18: 2354-2362.

117 Hanna N, Shepherd FA, Fossella FV, et al. Randomized phase III trial of pemetrexed versus docetaxel in patients with non-small-cell lung cancer previously treated with chemotherapy. J Clin Oncol 2004; 22: 1589-1597.

118 Ramlau R, Gervais R, Krzakowski M, et al. Phase III study comparing oral topotecan to intravenous docetaxel in patients with pretreated advanced non-small-cell lung cancer. J Clin Oncol 2006; 24: 2800-2807.

119 Bonomi P, Langer C, O'Brien M, et al. Analysis of prognostic factors in patients with advanced relapsed/ refractory NSCLC: Cox regression analysis of a randomized phase III trial comparing docetaxel and paclitaxel poliglumex (PPX). J Clin Oncol 2006; 24: Suppl. 18, 374S.

120 Ramlau R, Bennouna J, Tan EH, et al. Phase III study of vinflunine versus docetaxel in patients (pts) with advanced or metastatic non-small cell lung cancer (NSCLC) previously treated with a platinum containing regimen. J Thorac Oncol 2007; 8: Suppl. 4, A3-A5. 
121 Cufer T, Vrdoljak E, Gaafar R, Erensoy I, Pemberton K, SIGN Study Group. Phase II, open-label, randomized study (SIGN) of single-agent gefitinib (IRESSA) or docetaxel as second-line therapy in patients with advanced (stage IIIb or IV) non-small-cell lung cancer. Anticancer Drugs 2006; 17: 401-409.

122 Niho S, Ichinose Y, Tamura $\mathrm{T}$, et al. Results of a randomized Phase III study to compare the overall survival of gefitinib (IRESSA) versus docetaxel in Japanese patients with non-small-cell lung cancer who failed one or two chemotherapy regimens. J Clin Oncol, 2007: Suppl. 20, 18S.

123 Douillard JY, Kim E, Hirsh V, et al. Gefitinib (IRESSA) versus docetaxel in patients with locally advanced or metastatic non-small-cell lung cancer pre-treated with platinum-based chemotherapy: a randomized, open-label Phase III study (INTEREST). J Thorac Oncol 2007; 8: Suppl. 4, S305-S306.

124 Bria E, Cuppone F, Ciccarese M, et al. Weekly docetaxel as second line chemotherapy for advanced non-small-cell lung cancer: meta-analysis of randomized trials. Cancer Treat Rev 2006; 32: 583-587.

125 Chen YM, Shih JF, Perng RP, et al. A randomized trial of different docetaxel schedules in non-small cell lung cancer patients who failed previous platinum-based chemotherapy. Chest 2006; 129: 1031-1038.

126 Camps C, Massuti B, Jimenez A, et al. Randomized phase III study of 3-weekly versus weekly docetaxel in pretreated advanced non-small-cell lung cancer: a Spanish Lung Cancer Group trial. Ann Oncol 2006; 17: 467-472.

127 Gridelli C, Gallo C, Di Maio M, et al. A randomised clinical trial of two docetaxel regimens (weekly vs 3 week) in the second-line treatment of non-small-cell lung cancer. The DISTAL 01 study. Br J Cancer 2004; 91: 1996-2004.

128 Takeda K, Negoro S, Tamura T, et al. Docetaxel (D) versus docetaxel plus gemcitabine (DG) for second-line treatment of non-small cell lung cancer (NSCLC): results of a JCOG randomized trial (JCOG0104). Proc Am Soc Clin Oncol 2004; 23: Abstract 7034.

129 Shih C, Habeck LL, Mendelsohn LG, et al. Multiple folate enzyme inhibition: Mechanism of a novel pyrrolopyrimidine-based antifolate LY231514 (MTA). Adv Enzyme Regul 1998; 38: 135-152.

130 Hanauske AR, Chen V, Paoletti P, et al. Pemetrexed disodium: a novel antifolate clinically active against multiple solid tumors. Oncologist 2001; 6: 363-373.

131 Niyikiza C, Baker SD, Seitz DE, et al. Homocysteine and methylmalonic acid: markers to predict and avoid toxicity from pemetrexed therapy. Mol Cancer Ther 2002; 1: 545-552.

132 Vogelzang NJ, Rusthoven JJ, Symanowski J, et al. Phase III study of pemetrexed in combination with cisplatin versus cisplatin alone in patients with malignant pleural mesothelioma. J Clin Oncol 2003; 21: 2636-2644.

133 Pujol JL, Paul S, Chouaki N, et al. Survival without common toxicity criteria grade $3 / 4$ toxicity for pemetrexed compared with docetaxel in previously treated patients with advanced non-small cell lung cancer (NSCLC): a risk-benefit analysis. J Thorac Oncol 2007; 2: 397-401.
134 Scagliotti G, Purvish P, von Pawel J, et al. Phase III study of pemetrexed plus cisplatin versus gemcitabineplus cisplatin in chemonaive patients with locally advanced or metastatic non-small cell lung cancer. J Thorac Oncol 2007; 8: Suppl. 4, S306.

135 European Medicines Agency. EPARs for authorised medicinal products for human use. Alimta European Public Assessment Report. http:/ / www.emea.europa.eu/ humandocs/Humans/EPAR/alimta/alimta.htm Date last accessed: August 26, 2008. Date last updated: August 26, 2008.

136 Socinski MA, Steagall A, Gillenwater H. Second-line chemotherapy with 96-hour infusional paclitaxel in refractory non-small cell lung cancer: report of a phase II trial. Cancer Invest 1999; 17: 181-188.

137 Socinski MA, Schell MJ, Bakri K, et al. Second-line, lowdose, weekly paclitaxel in patients with stage IIIB/IV non small cell lung carcinoma who fail first-line chemotherapy with carboplatin plus paclitaxel. Cancer 2002; 95: 1265-1273.

138 Juan O, Albert A, Ordono F, et al. Low-dose weekly paclitaxel as second-line treatment for advanced nonsmall cell lung cancer: a phase II study. Jpn J Clin Oncol 2002; 32: 449-454.

139 Buccheri G, Ferrigno D. Second-line weekly paclitaxel in patients with inoperable non-small cell lung cancer who fail combination chemotherapy with cisplatin. Lung Cancer 2004; 45: 227-236.

140 Sculier JP, Berghmans T, Lafitte JJ, et al. A phase II study testing paclitaxel as second-line single agent treatment for patients with advanced non-small cell lung cancer failing after a first-line chemotherapy. Lung Cancer 2002; 37: 73-77.

141 Ceresoli GL, Gregorc V, Cordio S, et al. Phase II study of weekly paclitaxel as second-line therapy in patients with advanced non-small cell lung cancer. Lung Cancer 2004; 44: 231-239.

142 Yasuda K, Igishi T, Kawasaki Y, et al. Phase II study of weekly paclitaxel in patients with non-small cell lung cancer who have failed previous treatments. Oncology 2004; 66: 347-352.

143 Berghmans T, Lafitte JJ, Lecomte J, et al. Second-line paclitaxel in non-small cell lung cancer initially treated with cisplatin: a study by the European Lung Cancer Working Party. Br J Cancer 2007; 96: 1644-1649.

144 Esteban E, González de Sande L, Fernández Y, et al. Prospective randomised phase II study of docetaxel versus paclitaxel administered weekly in patients with non-small-cell lung cancer previously treated with platinum-based chemotherapy. Ann Oncol 2003; 14: 1640-1647.

145 Jacoulet P, Dubiez A, Westeel V, Polio JC, Pernet D, Depierre A. Chimiothérapie de deuxième ligne chez les patients réfractaires et résistants atteints de cancers du poumon non à petites cellules [Second-line chemotherapy among refractory and resistant patients with nonsmall cell lung cancers]. Rev Mal Respir 1997; 14: 29-35.

146 Camps C, Martinez EN, Jaime AB. Second-line treatment with gemcitabine and vinorelbine in non-small-cell lung cancer (NSCLC) cisplatin failures: a pilot study. Lung Cancer 2000; 27: 47-53. 
147 Hainsworth JD, Burris HA 3rd, Litchy S, et al. Gemcitabine and vinorelbine in the secondline treatment of nonsmall cell lung carcinoma patients: a minnie pearl cancer research network phase II trial. Cancer 2000; 88: 1353-1358.

148 Kosmas C, Tsavaris N, Panopoulos C, et al. Gemcitabine and vinorelbine as second-line therapy in non-small-cell lung cancer after prior treatment with taxane+platinumbased regimens. Eur J Cancer 2001; 37: 972-978.

149 Agelaki S, Bania H, Kouroussis C, et al. Vinorelbine-based regimens as salvage treatment in patients with advanced non-small cell lung cancer: two parallel multicenter phase II trials. Oncology 2001; 60: 235-241.

150 Makrantonakis P, Ziotopoulos P, Agelidou A, et al. Vinorelbine and cisplatin combination in pretreated patients with advanced non-small cell lung cancer pretreated with a taxane-based regimen: a multicenter phase II study. Lung Cancer 2006; 53: 85-90.

151 Berghmans T, Gourcerol D, Lafitte JJ, et al. Mitomycin plus vinorelbine salvage chemotherapy in non-small cell lung cancer: a prospective study. Lung Cancer 2008; 61: 378-384.

152 Ngan VK, Bellman K, Panda D, Hill BT, Jordan MA, Wilson LL. Novel actions of the antitumor drugs vinflunine and vinorelbine on microtubules. Cancer Res 2000; 60: 5045-5051.
153 Etiévant C, Kruczynski A, Chansard N, et al. Characterization of apoptosis induced by vinflunine, a novel fluorinated vinca alkaloid, in sensitive and vinflunine resistant P388 tumor cells: concomitant cell cycle analysis. Proc Am Assoc Cancer Res 1998; 39: 166.

154 Kruczynski A, Astruc J, Ricome C, Colpaert F, Hill BT. Definite antitumour activity of vinflunine, a novel fluorinated vinca alkaloid, against human tumour xenografts. Contrib Oncol Basel Karger 1999; 54: 369-378.

155 Ngan VK, Bellman K, Hill BT, Wilson L, Jordan MAL. Mechanism of mitotic block and inhibition of cell proliferation by semisynthetic vinca alkaloids vinorelbine and its new derivative vinflunine. Mol Pharmacol 2001; 60: 225-232.

156 Lobert S, Ingram JW, Hill BT, Correia JJ. A comparison of thermodynamic parameters for vinorelbine- and vinflunine-induced tubulin self-association by sedimentation velocity. Mol Pharmacol 1998; 53: 908-915.

157 Bennouna J, Breton JL, Tourani JM, et al. Vinflunine - an active chemotherapy for treatment of advanced nonsmall-cell lung cancer previously treated with a platinum-based regimen: results of a phase II study. $\mathrm{Br}$ J Cancer 2006; 94: 1383-1388.

158 Stinchcombe TE, Socinski MA. Considerations for second-line therapy of non-small cell lung cancer. Oncologist 2008; 13: Suppl. 1, 28-36. 